\title{
Review of e-learning Practice at the Tertiary Education level in Malaysia
}

\author{
Fahmeeda Adib Azhari ${ }^{1}$ and Long Chiau Ming ${ }^{1,2^{*}}$ \\ ${ }^{1}$ Faculty of Pharmacy, Universiti Teknologi MARA, Puncak Alam, Selangor, Malaysia. \\ ${ }^{2}$ Brain Degeneration and Therapeutic Group, Pharmaceutical and Life Sciences CoRe, Universiti Teknologi MARA, Shah Alam \\ Selangor, Malaysia.
}

\begin{abstract}
Introduction: The term e-learning can be described as the usage of electronic devices along with or without the help of internet to conduct a learning environment where it can be beneficial for the student. Nowadays e-learning is being integrated in the tertiary education to provide a better learning environment for the student. The review presents the current practice of e-learning at the tertiary education level in Malaysia. Methodology: A database search of PubMed, Science Direct, and Google scholar was conducted using terms such as e-learning, web-based learning, online learning, virtual learning, mobile learning. Results and Discussion: E-learning is not a new trend of teaching and learning method in the Malaysian education system and already been implemented in some of the universities in Malaysia. In this review, perception of lectures and students on e-learning interventionwere described to understand how well e-learning is being accepted in the education system.Besides that, we also mention the barriersand impact of e-learning implementation on students and the institution itself. Implementation of e-learning in health science andpharmacy education had received mixed responses. More studies on e-learning implementation especially on pharmacy education are needed. Conclusion: By understanding the current e-learning practice in Malaysia universities, it will enable continuous improvement on the e-learning programme so that it can be beneficial to all.
\end{abstract}

Key words: blended learning, Education research, Handheld computers, Internet, Information science, Software, Online learning.

\section{INTRODUCTION}

The increasing use of web-based technology and internet in the educational system is a global trend, especially in tertiary education. One of the earliest applications of web-based technology is e-learning (electronic learning), where the learning process involved mostly the use of computer devices with software program. E-learning was first designed to give opportunities to those who are unable to receive formal education as full-time students. This group of students include working adults who are interested in continuing their studies while working at the same time. ${ }^{1}$ Today, the function of e-learning is expanded to include all students, regardless of whether they are fulltime university students or distance learners.
E-learning is not a new phenomenon in Malaysia. In the late 1990s, universities in Malaysia started to implement e-learning in their education system. ${ }^{2,3}$ Even though there were issues such as lack of trained teachers, facilities, and student preparedness during the initial development of e-learning, the demand for e-learning has been increasing due to its flexibility, accessibility to reach a wider audience, andthe potential for cost reduction in the long term. ${ }^{4}$

Developing an effective e-learning environment requires a continuous and collaborative effort from a range of stakeholders, ranging from the students, the academic institutions to the government.
Submission Date : 07-03-2015 Revision Date : :23-04-2015 Accepted Date : :25-05-2015

DOI: $10.5530 / \mathrm{ijper} .49 .4 .2$ Correspondence Address Mr. Long Chiau Ming Level 11, FF1, Faculty of Pharmacy, Universiti Teknologi MARA (UiTM), 42300 Puncak Alam, Selangor, Malaysia. E-mail:ming.long@bath.edu

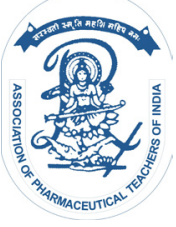
www.ijper.org 


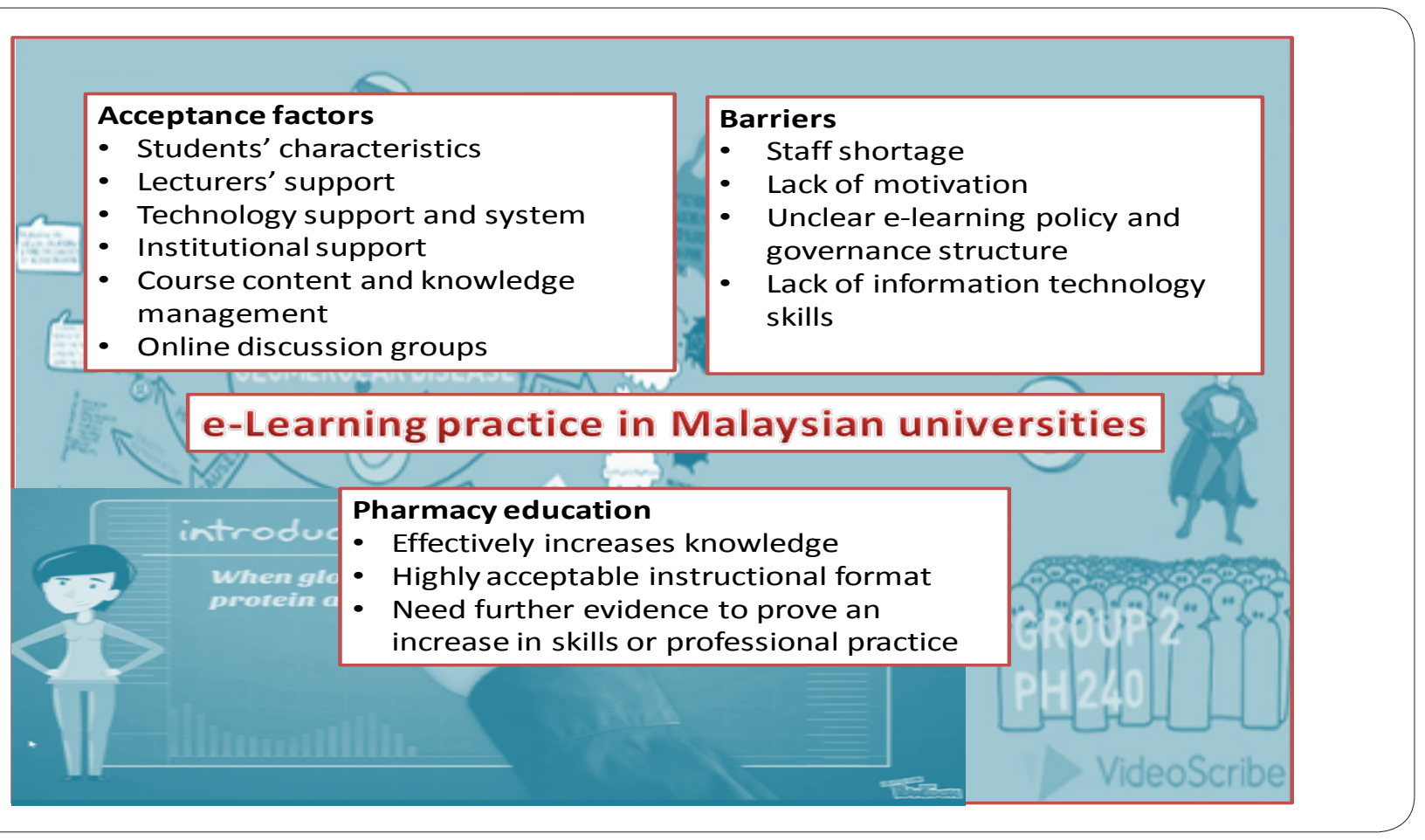

\section{Pictorial Abstract}

There are different terminologies used fore-learning. ${ }^{1}$ Researchers may have different interpretations for distance learning, online learning, and e-learning, depending on the learning objectives, content of study, target audience, and the mode of access to the learning environment. Distance learningis generally defined as a learning session between two parties (students and instructor) at different place and/or time and using several instructional materials. Online learning is defined as an access to learning session by using certain technology and some believed that online learning is the improved version of distance learning, ${ }^{1}$ whereas for e-learning, some researchers define e-learning based on the technology tools used in the learning environment, whether it strictly uses web-based technology or whether it includes the satellite broadcast and interactive television. For example, Ellis believed that e-learning is where the delivery method for the learning content involved CD-ROM, web-based technology, satellite broadcast, video- and audiotape, and interactive TV. ${ }^{5}$ Some authors also mentioned the use of constructivist theory model as the framework for e-learning. In this context, e-learning is defined as any education that uses the information and communication technologies (ICT) as a delivery method while enables students to build their knowledge based on their experience through the knowledge constructive process. ${ }^{1,6}$ We also identify e-learning technology tools based on the six categories mentioned in the recent reported study.
Embi stated that the success of e-learning implementation in tertiary education depends on various parties including the government, the institution, the academic staff, the lecturers, and the students. ${ }^{8}$ Thus, it is important for us to understand the problems and challenges faced by these different parties as to overcome any difficulties in implementing e-learning in the educational system. Although a number of studies have been done in tertiary education related to e-learning, not many studies focus on specific departments such as health science department., ${ }^{2,39-17}$ By doing the microscopic study of e-learning in specific departments such as in pharmacy education, generalizing the findings from the study is not allowed as it is only the fraction of the interested population. However, by understanding the students' perception on e-learning in a small scale, earlier modification can be made by the lecturers and academic staff as to motivate and overcome any problems faced by the students. The students' perception on e-learning intervention can be assessed through questionnaires or Likert-scale questionnaire. $^{7}$

Even though e-learning is widely practiced in tertiary education with in Malaysia, there are still problems and difficulties in the implementation of e-learning in universities. According to Embi, the problems in implementation e-learning are related to the governance of e-learning, e-content development, and issues faced both by the lecturers and students. ${ }^{8}$ Thus, it is vital for us to understand the student's perception on e-learning as they are one of the users of the system. Moreover, the 
study of the e-learning intervention in pharmacy education in Malaysia is limited. Therefore, the study on the practice of e-learning in pharmacy education is needed as to illustrate the most recent progress of e-learning practice in pharmacy education in Malaysia.

Although e-learning is being actively practiced in tertiary education in Malaysia, studies on the current practice of e-learning in health science are still lacking where it is especially noticeable among the pharmacy students. It is important to study the impact and students' perception on e-learning as to improvise the e-learning practice to create a more productive learning session. A study on the factors that may influence the effectiveness of e-learning is substantial as it will help the lecturers and policy-makers to identify the barriers faced during the e-learning implementation and find ways to overcome it.

This review focuses on e-learning implementation in the Malaysian tertiary education, perceptions of the lecturers and students on the e-learning intervention and the barriers faced along the implementation process. In addition, it also discusses the impact of e-learning implementation on the students and the institution itself. The literature review is then narrowed down into the implementation of e-learning in pharmacy education.

\section{METHODOLOGY}

\section{Source of Literature}

A database search of PubMed, Science Direct, and Google Scholar was conducted in English terms. The following terms were used:

- e-(or e) learning, web-based learning, online learning, virtual learning, mobile learning.

- Tertiary education, university.

- Barrier, difficulty, challenges.

- Perception, experience, students, lecturer, instructor, teacher.

- Health science student, medical student, pharmacy student, nursing student, optometry student.

\section{DISCUSSION}

The literature review of this paper focuses on the six categories of e-learning as to understand the current technology tools that are used in the e-learning process. It also discusses the current practice of e-learning in the Malaysian tertiary education including the barriers and facilitators during its implementation and the students and lectures' perceptions towards its implementation. Further more, this study also deliberates on the impact of e-learning on the students and the practice of e-learning in pharmacy education.

\section{Categories of e-learning}

E-learning intervention can be divided into six categories depending on the technologies used for the learning activities. This includes offline computer-based e-learning, online and local area network-based e-learning, psychomotor skills trainer, virtual reality environments, digital game-based learning, and m-learning. 7,18

The first e-learningcategory is offline computer-based e-learning, where the learning activities are done through personal computer or laptop without using the internet connection. The delivery method of the learning materials can be done either offline through compact disc, digital video disks or USB memory stick, or online through the network connection noting that the ongoing learning activities do not depend on this connection. ${ }^{7,18}$ This type of e-learningis normally being utilized in the remote areas with poor network connection in effort to overcome difficulty of accessing the e-learning online. ${ }^{18} \mathrm{~A}$ study by Rasmussen et al. suggested that offline e-learning is equivalent and might be better than traditional learning in terms of knowledge, skills, attitude, and satisfaction among the students. ${ }^{18}$ Thus, it will be beneficial for the education system to include the offline e-learningin the traditional learning system.

The second e-learning category is online and local area network-based e-learning, where the learning activities fully depend on the internet and intranet networks. The network connection uses the internet protocol and transmission control protocol to deliverthe e-learning materials to the students. ${ }^{7}$ The accessibility to the internet is one of the major factorsthat contribute to the successful implementation of the online e-learning. ${ }^{19}$ According to the International Telecommunication Union, 17.7 million out of 29.1 million population in Malaysia are internet users. ${ }^{20}$ With the increased accessibility of internet in various places and increased usage of the internet among Malaysians, it is believed that it will bring a positive influence towards the usage of online e-learning in Malaysia.

The third category of e-learning is the psychomotor skills trainer, where the e-learning is being used to train good motor coordination skills and techniques in education, such as learning the correct ways of handling instruments of tools. ${ }^{7}$ A study by Cantarero-Villaneuva showed that e-learning technologies can be used as additional tools to improve students' acquirement of the on hand manual skills for patient physical examination and diagnosis. $^{21}$

In virtual reality environment, a real or artificial environment is generated in the computer, enabling the user 
to interact with the external environment. ${ }^{7}$ To enhance the sensation of an immersion into the virtual world, the data arevisualizedin the form of three-dimensional and an interactive environment is provided following the specific subject available. The ability of the virtual environment to support multiple users simultaneously will enable the users to interact virtually and promote collaborative learning. ${ }^{22}$

The fifth e-learning intervention is the digital gamebased learning, where the learning application uses the principle of games and mechanics in non-game contexts to encourage students to complete the given tasks and improve their enthusiasm, attitude, and understanding. ${ }^{7}$ In this type of e-learning intervention, the self-initiated learning is developed, where the game developer used the users' enjoyment as the catalyst to stimulate the learning process. This is done to overcome the lack of users' initiatives to study when using the other types of e-learning environment. ${ }^{23}$

The sixth category of e-learning is the m-learning (mobile learning), where an e-learning intervention uses the mobile platform such as mobile phone or tablet to deliver the educational materials. ${ }^{7}$ According to a study done at Open University Malaysia (OUM), m-learning in tertiary education is believed to be able to help students to manage their time to study more properly and motivate them to study. ${ }^{24}$ Thus, the application of m-learning is encouraged to be used as one of the aids for learning as it will give beneficial effects to the students.

\section{E-learning practice in the Malaysian education system}

\section{Current practice of e-learning in Malaysia}

Generally, e-learning can be categorized into two phases where the differences between these two phasesare based on the tools of technology used to conduct the learning activities. In the first phase, the tools that have been used include the audio cassettes, video tapes with books and notes, whereas in the second phase the use of technology is more focused on the internet and computers. ${ }^{25}$ Here in Malaysia, Marlia et al. stated that e-learning in Malaysia occurs in two forms, which are paperless, and a combination of paper-based and electronic-based. ${ }^{25}$

The implementation of e-learning began to take place in the Malaysian tertiary education when the Educational Technology Division was first set up by the Ministry of Education in 1972. ${ }^{19}$ The rapid growth of technologies and wide availability of the internet in various places have encouraged many universities to start incorporating e-learning in their educational system. ${ }^{19}$ For example, Universiti Teknologi Malaysia has started implementing e-learning in their educational system since 1997 that allows the lecturers to post the class schedules, course outlines, and lecture notes for the students online ${ }^{2}$ and in the following year, 1998, e-learning was implemented in Universiti Tun Abdul Razak (UNITAR). ${ }^{3}$ UNITAR was initially a virtual university; however, it eventually has to change into hybrid learning due to the incapability of the Malaysian IT infrastructure to support it and due to the lack of knowledge of virtual university among the intended learners. ${ }^{25}$ Another university that takes great importance of e-learning is the OUM, which is the first open and distance learning institution in Malaysia. The educational system in OUM offerse-learning, face-toface tutorials, and self-managed learning as their modes of learning. ${ }^{24}$

Distance learning and e-learning are sometimes inter changeably used in the research writing. According to Goi et al, e-learning is the evolution from distance learning and they can be distinguished from each other based on paradigms in education, interactions involved and the technology that are used during the learning activities. ${ }^{19}$

In 2003, according to Hussin et al, a study by Multimedia University showed that only $65 \%$ of the universities in Malaysia provide e-learning and the main reasons for this implementation is due to the flexibility provided by e-learning. ${ }^{3}$ In 2004, a national e-readiness study conducted among students, academic staff, policy-makers, and industrial players showed that the level of readiness of Malaysia for e-learning was moderate. ${ }^{24}$

According to Yengin et al, one of the current developed technologies that facilitates the changing of e-learning to its current state is video streaming. ${ }^{26}$ In video streaming, the lecturers are able to record their own video and deliver their teaching materials to the students online with the help of the internet. ${ }^{26}$ In OUM, video streaming is currently being used as one of the tools for e-learning where they record the lecturers' slide presentation and video clips and it is also known as i-Tutorial. The method is believed to be beneficial for the students as the lecturers will explain the procedure step-by-step and in more interactive ways to help the students understand that particular subject. ${ }^{27}$ A study was also done at UTM, indicating the use of video streaming as a facilitating tool of learning among the deaf and hearingimpaired students where the video mostly consists of sign language and subtitles to help the students learn independently. ${ }^{28}$

Another tool that has been used to create changes in e-learning is audio file. Previously, audio files were consideredexclusive and costly to be produced and delivered but nowadays we can easily share it through the file sharing service. iTunes Universities is the current platform provided for the students to download educational 
audio and videos from different sources. ${ }^{26}$ Since current mobile phonesare already equipped with MP3 and MP4 players, OUM has also studied the students' preference on audio version of e-learning material in mobile learning. Based on the results, it showed that more than half of the students agreed to receive the audio version of the printed module in certain subjects. ${ }^{24}$

Another technology that caused the development of e-learning is the mobile learning. ${ }^{26}$ Currently with the tremendous growth of mobile technology along with the easy access of internet in various places, mobile learning is being actively studied as one of the platforms used for learning purpose. ${ }^{24}$ Based on a study done at OUM, the majority of students already possessed mobile phones and believed that they are ready to be engaged in mobile learning. ${ }^{24}$ An online survey on the mobile learning readiness of two local universities in Malaysia, namely Universiti Teknologi MARA (UiTM) and National University of Malaysia, in respect to the students' skills, psychology, and budgetwas also conducted. Based on the results, the majority of students readily welcome the idea ofimplementing mobile learning in their educational system as they are already familiar with the device. However, some of the students still feel hesitant when it concerns the monetary issues as they are unsure in what way their financial will be affected by applying mobile learning. ${ }^{29}$

\section{Students and teachers' perceptions towards e-learning}

As e-learning has become one of the popular practices for learning and teaching among students and lecturers, the needs to understand the students' perception on this matter has become vital. It is important to understand the students' acceptance of e-learning as part of their learning modes and its benefits so that later on, improvement can be made by the lecturers and policymakers.

A study was done at OUM in 2008 showing that the level of acceptance of e-learning among students at that time was moderate. ${ }^{10}$ In contrast, Yiong et al. cited another research showing that students in some universities in Malaysia had a below average level of acceptance for e-learning as they stated that they required time to adapt to the unfamiliar and new environment of e-learning. ${ }^{10}$ The differences in the levels of acceptance among students can be due to several factors such as students' characteristics, lecturers' support, technology support and system, institutional support, course content and knowledge management, and online discussion groups. ${ }^{10}$

According to Thayalan et al, it was suggested that virtual communication has decreased the gender-influenced inequalities that often occur in the face-to-face communication. ${ }^{9}$ Based on his study at UiTM Sabah, it showed that the perception of the students in e-learning is influenced by a gender difference where female students felt more sense of community compared to male students and thus causing differences in communicative styles during thee-learning activities. ${ }^{9}$ Several of the male students claimed that they are more straightforward on stating their opinions and unaware with the presence of others in online environment, whereas most of the female students are more conscious with the presence of others and more friendly towards other students. ${ }^{30}$ The influence of gender on e-learning perception was also mentioned in a study by Tasir et al, where it showed that the female students appeared to be more skill ful and ready for using social networking tools compared to the male students. However, this contradicts a study by Yacob et al. at TATi College Terengganu where it showed that there is no gender difference in the awareness of e-learning implementation. ${ }^{31}$ Since e-learningpurely depends on the language as a cue for communication rather than physical appearance, the effect of gender difference in e-learning perception is not as prominent as in traditional learning. ${ }^{9}$

Student perception on e-learning can be measured through their belief on the benefits of e-learning, relevance of the e-learning content, and e-learning functionality. ${ }^{32}$ In terms of the benefits, it can be assessed through their thoughts on the knowledge gained, confidence, stimulant interest, and usefulness of online discussions. In terms of the relevance of e-learning content, a study was done on university students of OUM, UNITAR, and International Islamic University showing that the majority of students are satisfied with the content as long as it is well organized and easy to understand. Another study was also done at OUM and UNITAR in the same year (2009), showing that the students perceived e-learning content as one of the important elements in e-learning due to the fact that the adult learners understand what they would gain at the end of the program. ${ }^{19}$ Besides that, most of the students were satisfied with discussion forums as they believed it will provide a platform for the students to ask questions and engage discussions with different lecturers at any time. ${ }^{3,21}$ Another benefit of discussion forum is that it allows students to lead their own discussion, to share knowledge among peers, and time for the students to deliver their ideas in a clearer way, ${ }^{3}$ whereas for e-learning functionality, since e-learning utilizes the web technology, the students' belief on the usefulness of e-learning can be measured by following the technology acceptance model. ${ }^{2}$ 
Aside from changing the style of learning, e-learning also affects the style of teaching. In other words, the lecturers are also affected by the implementation of e-learning in the educational system and thus their opinions regarding this educational technology must also be taken into account. ${ }^{33}$

Before applying the e-learning practice in the educational system, lecturers are exposed in advance with the e-learning policy and e-learning training. Based on the research funded by the Malaysian Ministry of Education, most $(92.5 \%)$ of the academic staff in tertiary education were aware of the existence of e-learning policy in their institutions. ${ }^{8}$ Embi stated that in conjunction with the academic staff awareness of this policy; they also have been actively following the guidelines stated on the policy to carry out the e-learning activity. ${ }^{8}$ The information regarding the e-learning policy is provided through the formal training programs, institutional websites, guidebooks or booklets, circulars or memos, and induction programs. ${ }^{34}$

In terms of e-learning training for lecturers, the majority of universities in Malaysia use the academic staff training and development programs as a medium to incorporate the e-learning training. ${ }^{8}$ Following the training given to the academic staff, the majority of them felt that e-learning training was effective and they have effectively used the knowledge gained to be applied in their teaching. ${ }^{8}$ Embi stated that even though the majority of academic staff in the higher education had a high level of awareness on e-learning, the lecturers' efforts in improving e-learning is considered to be lesser compared to other contributors such as top management, faculty department, and students. ${ }^{8}$ This result also correlated withthe study by Abas at OUM, where not all the instructors were able to support one of the e-learning elements which is the online discussion as they are rarely present in these classes. ${ }^{24}$

In the e-learning environment, lecturers play an important role to provide learning materials by using the provided technology. They also have the role to facilitate the students to obtain new knowledge and skills instead of directly hand in the knowledge to the students. ${ }^{26}$ Aside from that, in the early introduction of the course, lecturers have the responsibility to encourage students to be involved in utilizing the e-learning. However, the amount of their interaction with students must be in control as to not interrupt the interaction between students because following the social constructivism theory, social interaction between students can help them to actively construct their own understanding and knowledge, hence giving them the best learning environment. ${ }^{34}$ The benefits of e-learning are that it allows lecturers to assign the students with tasks and communicate with the students outside the lecture time. ${ }^{33}$

In terms of acceptance of e-learning among the lecturers, according to Hsbollah et al, gender and age of lecturers do not affect the acceptance towards e-learning. ${ }^{33} \mathrm{~A}$ study done at Universiti Utara Malaysia showed that the more likely factors that influence lecturers' acceptance is how the lecturers themselves perceive the benefits of e-learning and the degree of testing the technology prior to using it. ${ }^{33}$

\section{Barriers and facilitators for e-learning}

Based on the study by Embi, the major barriers in the implementation of e-learning in tertiary education institution in Malaysia are shortage of workers (84.5\%) and lack of motivation among those who are involved in implementing e-learning. ${ }^{8}$ In addition, there are also issues of unclear e-learning policy and governance structure and poorly stated outlines of responsibility on the task of planning and implementing e-learning. Some people also viewed the absence of e-learning center and inadequate support from the top management as the main challenges. Improvements that have been proposed to overcome these problems include establishment of a National Institute of e-learning under the supervision of the Malaysian Ministry of Education to provide clear guidelines on e-learning policies, incentives are given to the academic staff, and continuous monitoring of the new and existing lecturer's training. ${ }^{8}$

In relation to academic staff, universities in Malaysia are facing challenges such as academic staff are not very knowledgeable in Information Technology (IT), academic staff do not have time to apply the e-learning intervention as they are too busy with research and heavy teaching load, and some of them still feel doubtful of e-learning effectiveness. As fore-learning training, the main challenges faced by universities are moderate motivation among the lecturers and instructors, and low attendance during training. One of the main causes that leads to low attendance is inappropriate training schedule that occurs in the middle of the semester where most of the lecturers are occupied with their teaching schedules. ${ }^{8}$ The solutions that have been proposed to overcome these problems include exposure of the new technologies such as Web 2.0 and Web 3.0 to the academic staff, providing policy for e-learning training coordination in all universities by Malaysian Ministry of Education, and providing more flexible training schedule as to allow more lecturers to participate in the program. ${ }^{8}$

In terms of teaching and learning session, lecturers are facing difficulties in managing their time between research and teaching alongside with the time constraint to prepare the materials for e-learning session. ${ }^{8}$ OUM 
was also facing the same problem as not all the lecturers are present during the online discussions. To overcome this problem, OUM has started to change their method of supporting the online discussion where they are required to deliver three types of online presence which are teaching, cognitive, and social. ${ }^{24}$

As for students, the majority of them are facing problems such as difficulty in accessing the learning materials from the online e-learning medium, long response time from the lecturers, lack of contents, and time consuming. ${ }^{8}$ Those who are having difficulties in accessing the internet will perceive e-learning as inconvenient and will likely lose interest on it. Thus, it is important for the e-learning providers to ensure their materials are easily accessed regardless of the time and place. ${ }^{19}$ Some of them also faced a difficulty in motivating themselves to initiate the e-learning activity. To overcome this problem, a variety of graphic, color, sound, and animation have been used to attract and retain students' attention during the learning session. ${ }^{3}$

\section{Impact of e-learning}

Throughout the intervention of e-learningat the university level, we can see the positive impression of e-learning on theuniversity organizations. These include cost reduction in delivering teaching materials, increased ability of the network to accommodate higher amount of workload, and improved accessibility and availability of the teaching materials to distance learners. ${ }^{7}$ George $e t$ al. cited a paper stating that e-learning can be cost efficient if the current lecturers are actively involved in the content generation for their particular disciplines and thus the development of the contents would not require the involvement of many faculties at every stage. Goi et al. also cited a paper stating that with e-learning, the cost of university infrastructure can also be reduced as there will be no requirement to build a physical campus when the students are able to access the learning materials from their home. ${ }^{19}$

Furthermore, the ease of accessing learning materials regardless of time and place will enable the universities to reach out to a wider audience, hence enabling the institutions to grow at a faster rate. For example, OUM has successfully registered more than 60,000 students since its opening in 2000 and most of the OUM's students are working adults. ${ }^{3,24}$

The impact of e-learning on students can be studied by assessing the students' knowledge, skills, and attitudes. ${ }^{7}$ The impact of e-learning intervention on students' knowledge can be assessed through a number of ways such as by using multiple choice questions, gap text questions, short essay questions, matching and short answer questions, and open ended questions. ${ }^{7}$ Based on the systemic review by George et al, 27\% of the reviewed research from various disciplines showed a significant increase of knowledge after the e-learning intervention compared to traditional learning where $48 \%$ of the reviewed research showed no significant difference of knowledge between e-learning and traditional learning. ${ }^{7}$

On the other hand, a review by Salter et al. showed that all the reported studies had a significant immediate increase of knowledge in pharmacy education after the exposure of the e-learning method with difference only on the magnitude of the knowledge gained. This indicates that e-learning does leave positive changes in the knowledge gained.However, there is no significant difference of the knowledge gained by e-learning method or traditional learning method. ${ }^{32}$

As for students' skills, it can be assessed by using rating scale, search skill test, Likert-type questionnaire, and written assessments such as data collection sheets. ${ }^{7}$ A systemic review was done in 2014, showing that the majority of students do acquire greater skills on handling devices and performing procedures after the intervention of e-learning compared to the traditional learning process. ${ }^{7}$

For students' attitudes towards e-learning, it can be measured by using questionnaires or Likert-scale questionnaire. ${ }^{7}$ Based on the systemic review by George et al, the majority of research do not show any significant difference in the students' attitudes between the e-learning and traditional learning method. ${ }^{7}$

\section{E-learning practice in health science education}

Several studies have shown the application of e-learning among health science students. For example, the latest application of e-learning in the nursing education is the virtualpatients where it allows a more accessibility and cost effective cased-based learning program. ${ }^{14}$ Other than that, there are studies that showed the application of e-learning in medical education within low- and middle- income countries such as in South Africa andIndia where e-learning is adapted in hoping to overcome the limited shortage of medical faculty and to improve the accessibility of students to the learning materials. ${ }^{12}$ William stated that paramedical students also found computer-based learning to be useful for their learning; however, not all the students can accept the application of computer-based learning in the online environment as some of them are facing difficulties in accessing the internet other than in their university. ${ }^{17}$

In Malaysia, there are also studies of e-learning intervention done on health science faculties including the biomedical science, optometry, and nutrition and dietetics department. Based on the study at National University of Malaysia, these health science students believed 
that implementation of e-learning has become a great communication medium between the lecturers and students in acquiring and passing the lecture notes. However, they also believe that more improvements are required on the e-learning content as to make it more attractive and user-friendly. ${ }^{16}$ Furthermore, there is also study done at the Faculty of Medicine in UiTM on the students' perception of computer-assisted learning (CAL) which can be considered as one of the tools in e-learning intervention. Based on this study, it showed that most of the medical students believed that CAL has improved their learning experience and has allowed the students to learn more flexibly within their own pace while still following the time-table slot. ${ }^{13}$ On the other hand, according to Ahmad et al, a pilot study done on health science students showed that even though virtual learning can bring a lot of benefits to the students, the low speed of internet has become a great challenge for the implementation of this learning technique. ${ }^{11}$

\section{E-learning practice in pharmacy education}

E-learninghas also been incorporated in pharmacy education. ${ }^{36,37}$ According to Efferth, the under graduate pharmacy students have actively used e-learning to improve the attractiveness of learning pharmacology and microbiology. ${ }^{35}$ For instance, the e-learning applications used were virtual laboratory module and Teaching Resource Center Pharmacology database. ${ }^{38}$ Apart from that, validation of e-learning on the knowledge and acceptance was also reported and the majority of pharmacy students felt that e-learning is effective as well as a convenient way to be up-to-date with the current pharmacy-related issues. ${ }^{15,39} \mathrm{~A}$ systematic review on the effectiveness of e-learning in pharmacy education conducted using an assessment of perception on benefits of e-learning, relevance of specific learning course, and e-learning functionality was recently reported. ${ }^{32}$ This review found that e-learning in pharmacy education effectively increases knowledge and is a highly acceptable instructional format for pharmacists and pharmacy students, albeit the increment in terms of skills or professional practice has not been proven. ${ }^{32}$

In Southeast Asia, one of the universities in Thailand implementede-learning by introducing the social constructivist learning environment where the students can construct their knowledge during the process of social interaction with their friends. The e-learning processis conducted by following the social constructivism theory in hoping to encourage the social interaction between students and based on the students' perception, most of them agreed that working in groups are more effec- tive and they are satisfied with the activities conducted through an online environment. ${ }^{35}$

In Malaysia, there is limited study on the application of e-learning in pharmacy education. One of them includes the descriptive study of the students' perception towards e-learning management system. ${ }^{40}$ This study was done at Universiti Sains Malaysia, where the students believed that e-learning is useful and can improve their knowledge. However, they prefer e-learning to be used in the blended learning instead of using it alone. Another studyis related to the effectiveness of using video recording as one of the tools to teach pharmacy students in communication and counseling where by using this technique will allow the students to assess their own performance and identify the strength and weakness during the session. ${ }^{41}$ There are probably more studies of e-learning in pharmacy education; however, due to non-systemic literature review, some of the journals might be neglected or slipped out due to inadequate phrases used during the search.

\section{CONCLUSION}

E-learning is one of the learning methods that can be beneficial to both studentsand facilitators. The findings of the review show that there various improvement and activities that need to be performed to fully gain the benefits of e-learning. Despite an increase in the number of e-learning implementation, further research on the application of e-learning in specific subject areas such as pharmacy are needed. Strong positive evidence is essential to reflect the advantagesof e-learning and justify the fund allocation for e-learning in the university.

\section{ACKNOWLEDGEMENTS}

We would like to thank Dr Zoe Lim, Dr Tahir Mehmood Khan, Mr Mohammed Abdul Hameed for their comments and suggestions. This work was supported by ZAMALAH (600-RMI/DANA 5/3/PSF:5/2015). The authors would like to express their gratitude to Ministry of Education, Malaysia and Universiti Teknologi MARA, Malaysia for educational support for this research.

\section{ABBREVIATIONS}

e-learning: Electronic learning, ICT: Information and Communication Technologies, m-learning: Mobile learning, IT: Information Technology, OUM: Open University Malaysia, UiTM: Universiti Teknologi MARA, UNITAR: Universiti Tun Abdul Razak, CAL: Computer-assisted learning. 


\section{SUMMARY}

- The problems in implementation e-learning are related to the governance of e-learning and e-content development.

- e-learning in pharmacy education effectively increases knowledge and is a highly acceptable instructional format but the increment in terms of skills or professional practice has not been proven.

- Acceptance factors are students' characteristics, lecturers' support, technology support and system, institutional support, course content and knowledge management, and online discussion groups.

- Barriers for e-learning are shortage of related staffs and unclear e-learning policy and governance structure.

- Challengesamong academic are lack ofinformation technology skills and time to apply the e-learning module.

\section{About Authors}

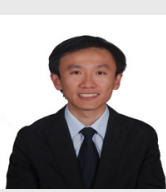

Dr Long CM: A senior lecturer in Faculty of Pharmacy, UniversitiTeknologi MARA (UiTM), Malaysia and a researcherat Brain Degeneration and Therapeutic Group, UiTM. He obtained his BPharm (Hons) and Master(Clinical Pharmacy) degrees from UniversitiSains Malaysia. Then, he underwent $\mathrm{PhD}$ training in University of Bath, UK. He teaches research methodology, pharmacoinformatics and clinical pharmacy subjects since 2007. He has a special interest in pharmacy education and holds a
Certification in Education. Till May 2015 he has more than 20 journal publications; 20 conference abstracts and 2 book chapters. He had been awarded 9 research grants with a total amount of RM800k. He is actively supervising postgraduate students on research on pharmacy practice and pharmaceutical sciences.

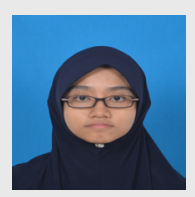

Fahmeeda Adib Azhari: A Bachelor of Pharmacy (Honours) student in Faculty of Pharmacy, UiTM, Malaysia. She is the recipient of scholarship award from Public Service Department of Malaysia.

\section{REFERENCES}

1. Moore JL, Dickson-Deane C, Galyen K. e-Learning, online learning, and distance learning environments: Are they the same? Internet High Educ. 2011; 14(2): 129-35.

2. Masrom M. Technology acceptance model and e-learning. $12^{\text {th }}$ International Conference on Education, Sultan Hassanal Bolkiah Institute of Education (2007). Available from: https://www.researchgate.net/profile/Maslin_ Masrom2/publication/228851659_Technology_acceptance_model_and_Elearning/links/544f08aa0cf2bca5ce90c393.pdf. Technpdf Accessed January 10, 2015.

3. Hussin H, Bunyarit F, Hussein R. Instructional design and e-learning: Examining learners' perspective in Malaysian institutions of higher learning. Campus-Wide Inform Syst. 2009; 26(1): 4-19.

4. Ali A. Issues \& challenges in implementing e-learning in Malaysia (2004). Available from: http://www.nottingham.ac.uk/ ntzcl1/literature/elearning/ malaysia.pdf. Accessed Feb 18, 2015.

5. Ellis R. Down with Boring E-Learning! Interview with e-learning guru $\mathrm{Dr}$ Michael W Allen (2004). Available from: http://wwwlearningcircuitsorg/2004/ jul2004/allenhtm Accessed February 18, 2015.

6. Tavangarian D, Leypold ME, Nölting K, Röser M, Voigt D. Is e-learning the Solution for Individual Learning. Electron J E-Learn. 2004; 2(2): 273-80.

7. George PP, Papachristou N, Belisario JM, et al. Online eLearning for undergraduates in health professions: A systematic review of the impact on knowledge, skills, attitudes and satisfaction. J Global Health. 2014; 4(1): e1-17.

8. Embi MA. e-Learning in Malaysian institutions of higher learning: Status, trends and challenges. Paper presented at: International Lifelong Learning Conference (ICLLL 2011), Seri Pacific Hotel, Kuala Lumpur, 2011.

9. Thayalan X, Shanthi A, Paridi T. Gender difference in social presence experienced in e-learning activities. Procedia Soc Behav Sci. 2012; 67: 580-9.

10. Yiong BLC, Sam HK, Wah TK. Acceptance of e-learning among distance learners: A Malaysian perspective. Paper presented at: In Hello! Where are you in the landscape of educational technology? Proceedings ascilite Melbourne 2008. Available from: http://www.ascilite.org.au/conferences/ melbourne08/procs/lim.pdf. Accessed February 18, 2015.

11. Ahmad NSHN, Wana TR, Jiang P. Learning health through virtual world: comparative between UK and Malaysia. Procedia Soc Behav Sci. 2010; 9: 11-20.

12. Frehywot $\mathrm{S}$, Vovides $\mathrm{Y}$, Talib $\mathrm{Z}$, et al. E-learning in medical education in resource constrained low-and middle-income countries. Hum Resour Health. 2013; 11(1): 4.
13. Govindaraja C, Jaiprakash H, Annamalai C, Vedhavathy SS. Computer assisted learning: Perceptions and knowledge skills of undergraduate medical students in a Malaysian medical school. Natl J Physiol Pharm Pharmacol. 2011; 1(2): 63-7.

14. Koch LF. The nursing educator's role in e-learning: A literature review. Nurs Educ Today. 2014; 34(11): 1382-7.

15. Nesterowicz K, Librowski T, Edelbring S. Validating e-learning in continuing pharmacy education: user acceptance and knowledge change. BMC Med Educ. 2014; 14(1): 33.

16. Saat NZM, Chong P, Omar B, et al. Knowledge, perception and practice on the usage of e-learning among health students in Kuala Lumpur. Procedia Soc Behav Sci. 2012; 60: 610-14.

17. Williams B. Qualitative analysis of undergraduate paramedic students' perceptions of using case-based learning in an online learning environment. J Emerg Prim Health Care. 2006; 4(3): e1-6.

18. Rasmussen $\mathrm{K}$, Belisario JM, Wark PA, et al. Offline eLearning for undergraduates in health professions: A systematic review of the impact on knowledge, skills, attitudes and satisfaction. J Global Health. 2014; 4(1): e1-18.

19. Goi CL, Ng PY. E-learning in Malaysia: Success factors in implementing e-learning program. Int J Teach Learn High Educ. 2009; 20(2): 237-46.

20. International Telecommunication Union. World Telecommunication/ICT Indicators database 2014. Available at: http://www.itu.int/en/ITU-D/Statistics/ Pages/stat/default.aspx. Accessed February 12, 2015.

21. Cantarero-Villanueva I, Fernández-Lao C, Galiano-Castillo N, Castro-Martín E, Díaz-Rodríguez L, Arroyo-Morales M. Evaluation of e-learning as an adjunctive method for the acquisition of skills in bony landmark palpation and muscular ultrasound examination in the lumbopelvic region: a controlled study. J Manipulative Physiol Ther. 2012; 35(9): 727-34.

22. Monahan T, McArdle G, Bertolotto M. Virtual reality for collaborative e-learning. Comp Educ. 2008; 50(4):1339-53.

23. Fu F-L, Su R-C, Yu S-C. EGame Flow: A scale to measure learners' enjoyment of e-learning games. Comp Educ. 2009; 52(1): 101-12.

24. Abas ZW, Peng CL, Mansor N. A study on learner readiness for mobile learning at Open University Malaysia. IADIS International Conference Mobile Learning. 2009. 151-7.

25. Puteh M, Hussin S. A comparative study of e-learning practices at Malaysian private universities. In: 1st International Malaysian Educational Technology Convention (2007) Available from http://eprintsutmmy/4507/1/A_ 
Comparative_Study_of_E_Learning_at_Malaysian_Private_Universitiespdf Accessed January 12, 2015.

26. Yengin I, Karahoca D, Karahoca A, Ozcinar Z. Being ready for the paradigm shifts in e-learning: Where is the change happening and how to catch the change? Procedia Soc Behav Sci. 2010; 2(2): 5762-68.

27. Abas ZW, Khalid HM. Achieving pedagogical richness to meet the needs of ODL learners. In: Tsang P, Kwang R, Fox R, eds. Enhancing Learning Through Technology. London: World Scientific Publishing; 2007. 161-70.

28. Hashim H, Tasir Z, Mohamad SK. E-learning environment for hearing impaired students. Turkish Online J Educ Technol. 2013; 12(4): 67.

29. Hussin S, Manap MR, Amir Z, Krish P. Mobile learning readiness among Malaysian students at higher learning institutes. Asian Soc Sci. 2012; 8(12): 276.

30. Tasir Z, Al-Dheleai YMH, Harun J. Students' perception towards the use of social networking as an elearning platform. Available from: http://www.wseas. us/e-library/conferences/2011/Penang/EDU/EDU-10.pdf. Accessed January 10, 2015. 2011.

31. Yacob A, Kadir AZA, Zainudin O, Zurairah A. Student awareness towards E-learning in education. Procedia Soc Behav Sci. 2012; 67(1): 93-101.

32. Salter SM, Karia A, Sanfilippo FM, Clifford RM. Effectiveness of E-learning in pharmacy education. Am J Pharm Educ. 2014; 78(4): e1-12.

33. Hsbollah HM, Idris $\mathrm{KM}$. E-learning adoption: the role of relative advantages, trialability and academic specialisation. Campus-Wide Inform Syst. 2009; 26(1): 54-70.

34. Neoh CF, Zainal INA, Hameed MA, Khan TM, Ming LC. Development and progress of pharmacoinformatics in pharmaceutical and health sciences. JYP. 2015; 7(3): 155-63.
35. Sthapornnanon N, Sakulbumrungsil R, Theeraroungchaisri A, Watcharadamrongkun S. Social constructivist learning environment in an online professional practice course. Am J Pharm Educ. 2009; 73(1): e1-8.

36. Hadi MA, Long CM, Leng LW, Lylia RR, Adam A. A needs-based curriculum review for diploma in pharmacy programme at a Malaysian university. Arch Pharm Pract. 2011; 2(1): 23.

37. Long CM, Yee SM, Muhammad AM, Hussain M, Manan MM. Outcome base approach for a new pharmacoinformatics course for bachelor of pharmacy programme. In: Tang SF, Logonnathan L, eds. Taylor's 7th Teaching and Learning Conference 2014 Proceedings- Holistic Education: Enacting Change. Singapore: Springer; 2015: e1-13.

38. Efferth T. E-learning in pharmacology and pharmacy. Educ Sci. 2011; 1(1): 4-14.

39. Hadi MA, Long CM, Leng LW, Shaharuddin S, Adam A. Developing a practicebased master in clinical pharmacy program at the Universiti Teknologi MARA, Malaysia. Am J Pharm Educ. Mar 10 2010; 74(2): 32.

40. Mohamed Azmi H ZS, Fahad S, Maryam F, Hisham A. Assessment of students' perceptions towards e-learning management system (e-Ims) in a Malaysian pharmacy school: a descriptive study. Malays J Public Health Med. 2012; 12(1): 14-20.

41. Ali AM, Chiau TP, Paraidathathu T, et al. The effectiveness of feedback using video recording as a potential teaching method in communication and counselling among pharmacy students. Procedia Soc Behav Sci. 2012; 60(1): 254-8. 